\title{
A DC-DC Converter with Wide Input Voltage Range for Fuel Cell and Supercapacitor Application
}

Zhang, Zhe; Thomsen, Ole Cornelius; Andersen, Michael Andreas E.

Published in:

International Conference on Power Electronics and Drive Systems, 2009. PEDS 2009

Link to article, DOI:

10.1109/PEDS.2009.5385904

Publication date:

2009

Document Version

Publisher's PDF, also known as Version of record

Link back to DTU Orbit

Citation (APA):

Zhang, Z., Thomsen, O. C., \& Andersen, M. A. E. (2009). A DC-DC Converter with Wide Input Voltage Range for Fuel Cell and Supercapacitor Application. In International Conference on Power Electronics and Drive Systems, 2009. PEDS 2009 (pp. 706-711). IEEE. https://doi.org/10.1109/PEDS.2009.5385904

\section{General rights}

Copyright and moral rights for the publications made accessible in the public portal are retained by the authors and/or other copyright owners and it is a condition of accessing publications that users recognise and abide by the legal requirements associated with these rights.

- Users may download and print one copy of any publication from the public portal for the purpose of private study or research.

- You may not further distribute the material or use it for any profit-making activity or commercial gain

- You may freely distribute the URL identifying the publication in the public portal 


\title{
A DC-DC Converter with Wide Input Voltage Range for Fuel Cell and Supercapacitor Application
}

\author{
Zhe Zhang, Ole C. Thomsen and Michael A. E. Andersen \\ Department of Electrical Engineering \\ Technical University of Denmark \\ Kgs. Lyngby, Denmark, DK2800 \\ zz@elektro.dtu.dk
}

\begin{abstract}
This paper proposes a novel phase-shift plus duty cycle controlled hybrid bi-directional DC-DC converter based on fuel cells and supercapacitors. The described converter employs two high frequency transformers to couple the half-bridge and full-bridge circuits together in the primary side and voltage doubler circuit in secondary side. Boost type converter can limit the output ripple current of the fuel cells; hybrid full-bridge structure can change operating modes according to the different input voltage; phase-shift with duty cycle control scheme is utilized to control the bidirectional power flow flexibly. All the switches can turn on under zero-voltage-switching condition (ZVS). The operating principles of the converter are described in details, and the experimental results based on the prototype controlled by DSP are presented to verify the validity of the analysis and design.
\end{abstract}

Keywords-converter; dc-dc; bidirectional; soft-switching

\section{INTRODUCTION}

Nowadays, the hybrid system based on fuel cells (FCs) and supercapaciotrs (SCs) as an environmentally renewable energy system has been applied in many fields, such as hybrid electric vehicle (HEV), uninterruptible power supply (UPS) and so on. Fuel cells can convert the chemical potential of the hydrogen into electric power directly, with consequent high conversion efficiency and possibility to obtain the extended range with the combustible feed from the outside [1]. But one of the main weak points of the fuel cell is its slow dynamics because of the limitation of hydrogen delivery system. So during the fuel cells warming up or load requirement transient, the supercapacitors can be utilized as the auxiliary power source for smoothing output power. On the other hand, because the fuel cell output voltage varying widely, almost $2: 1$, depending on different load conditions, and the terminal voltage of supercapacitors bank is variable during charging and discharging periods, it is very important for the conversion system to be capable of harvesting power from different power sources and have good performance in widely variable input voltage range and load variations. Many hybrid system structures have been proposed, and they can be divided into four categories: DC bus structure [2], [3], transformer-coupled structure [4], [5], [6], multi-port structure [7] and multi-stage structure, [8], [9]. For the DC bus structure, each power source is connected by a separate converter to the common voltage DC bus. In this architecture, each subsystem could be design as an individual module, but the complicated control is the main disadvantage. In high

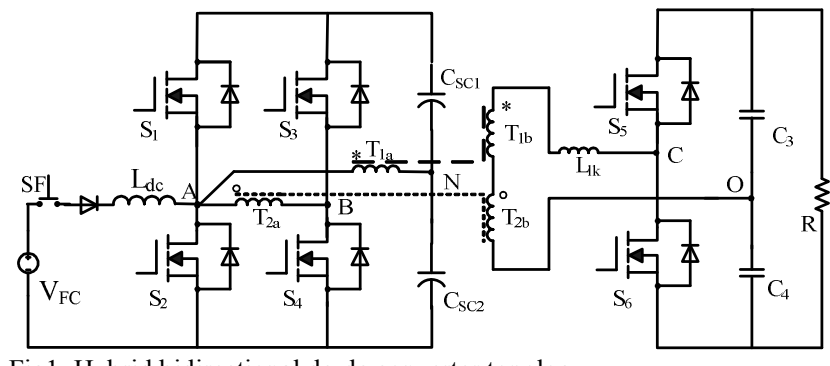

Fig1. Hybrid bidirectional dc-dc converter topology.

frequency transformer coupled system, transformer design and power flow control are the keys to decide the performance of the system. For the multi-stage structure, efficiency is limited by the cascaded converters.

It is proposed that a novel DC-DC converter, as shown in Fig. 1, with fuel cells as main input power source and supercapacitors are connected directly to the low voltage side in this paper. The converter utilizes the boost-type input structure to limit the ripple current of the FCs [10] and hybrid full-bridge structure [11], [12] to change operating modes in terms of the different input voltage values. Phase-shift plus duty cycle modulation scheme can control the bidirectional power flow flexibly. This paper is organized into five sections. Section II gives the operation principle of the proposed converter; Theoretical analysis, calculation and design results are present in Section III. Section VI shows the experimental results. Section V gives the conclusions.

\section{OPERATION PRINCIPLES}

As seen through Fig, 1, the boost type half bridge high frequency inverter with the switches operating by $50 \%$ duty cycle is in the primary side of the transformer, and supercapacitors $C_{\mathrm{SC} 1}$ and $C_{\mathrm{SC} 2}$ connect on the variable low voltage DC bus as the secondary energy source. $S_{3}$ and $S_{4}$ are controlled by duty-cycle, $d$, to change the operating modes, when input voltage is variable in the wide range. Two transformers, $T_{1}$ and $T_{2}$, with the paralleled primary windings and series-wound secondary windings are utilized to realize isolation and boost the low input voltage. Voltage doubler circuit in secondary side of the transformer is to get higher voltage conversion ratio. The leakage inductances of the transformers are the interface and energy transfer elements between the two high frequency inverters. 
According to different power flow directions, operational modes of the proposed converter can be divided into two modes, Boost mode and Buck mode. In Boost mode, the power is delivered from the fuel cells and supercapacitors to the high voltage DC bus, which means energy is from low voltage side to the high voltage side. The counterpart is defined as Buck mode. In different modes, Boost or Buck, there are several submodes as well depending on different input or output voltage value to limit the peak currents of the converter, respectively. The detailed operational modes are described as follows.

\section{A. Boost mode}

In Boost mode, when input voltage is around $30 \mathrm{~V}, S_{1}, S_{4}$ and $S_{2}, S_{3}$ will turn on synchronously. Phase-shift modulation is used to control the power delivered, as shown in Fig. 2. When the input voltage is higher than $30 \mathrm{~V}$, the converter will work under the multi-level operation sub-mode to limit the rms current value in the primary side of the transformers, through the duty cycle control on $S_{3}$ and $S_{4}$, as shown in Fig. 3 . If the output voltage, $V_{O}$, is controlled well, that means it can be seen as constant, we can define $d$ as:

$$
d=2 \pi \cdot \frac{T_{\text {on } S 3}}{T_{S}}=2 \pi \cdot\left(1-\frac{4 \cdot v_{F C}}{n_{1} \cdot V_{O}}\right) \quad(\mathrm{rad})
$$

Where $n_{1}$ is turn ratio of the transformer $\mathrm{T}_{1}$.

Because the 2-level operation is one special condition (duty cycle of $S_{3}$ and $S_{4}$ equal to 0.5 ) of the multi-level mode, only the multi-level sub-mode is analyzed in this paper. For the convenience of analysis, the following assumptions are given: (1) all the switches are ideal with anti-parallel body diodes and parasitic capacitors; (2) The inductance $L_{d c}$ is large enough to be treated as a current source; (3) Output voltage is controlled well which can be seen constant; (4) The two transformers are ideal and with series leakage inductor $L_{l k}$ in the secondary side. One complete switching cycle can be divided into ten intervals as shown in Fig. 3, and because of the similarity, only a half switching cycle in described in detail. The equivalent circuits are shown in Fig. 4.

1) Interval $1\left(t_{0}-t_{1}\right): S_{1}, S_{4}$ and $S_{6}$ are conducting. The voltage on $L_{l k}, v_{L l k}$, is $v_{T 1 b}+v_{T 2 b}+V_{C O}$, so the $i_{\mathrm{Llk}}$ will increase linearly. $I_{L d c}$ goes though $D_{\mathrm{S} 1}$.

2) Interval $2\left(t_{1}-t_{2}\right)$ : at $t_{1}, S_{6}$ is turned off. $L_{l k}, C_{\mathrm{S} 5}$ and $C_{\mathrm{S} 6}$ begin to resonate, $C_{\mathrm{S} 5}$ is discharged and $C_{\mathrm{S} 6}$ is charged. When voltage on $C_{\mathrm{S} 5}$ reduces to zero, the anti-paralleled diode of $S_{5}$ start to conduct, and the voltage $v_{C O}$ changes the direction. So $v_{L l k}$ equals to $v_{T 1 b}+v_{T 2 b}-V_{C O}$.

$3)$ Interval $3\left(t_{2}-t_{3}\right)$ : at $t_{2}, S_{5}$ is turned on under ZVS. The current paths are same with these in Interval 2.

4) Interval $4\left(t_{3}-t_{4}\right)$ : at $t_{3}, S_{4}$ is turned off. $L_{l k}, C_{\mathrm{S} 3}$ and $C_{\mathrm{S} 4}$ begin to resonate. When the voltage cross $S_{3}$ reduces to zero, $D_{\mathrm{S} 3}$ is therefore forward based. The voltage cross the primary winding of $\mathrm{T}_{2}$ is clamped to zero. So $v_{L l k}$ equals to $v_{T 1 b}-V_{C O}$.

5) Interval $5\left(t_{4}-t_{5}\right)$ : at $t_{4}, S_{1}$ is turned off. $L_{l k}, C_{\mathrm{S} 1}$ and $C_{\mathrm{S} 2}$ begin to resonate. $C_{\mathrm{S} 2}$ is discharged from $2 V_{F C}$. The rate of change depends on the magnitude $i_{\mathrm{T} 1 \mathrm{a}}+i_{\mathrm{T} 2 \mathrm{a}}-I_{\mathrm{Ldc}}$. At $t_{5}, v_{\mathrm{CS} 2}$.

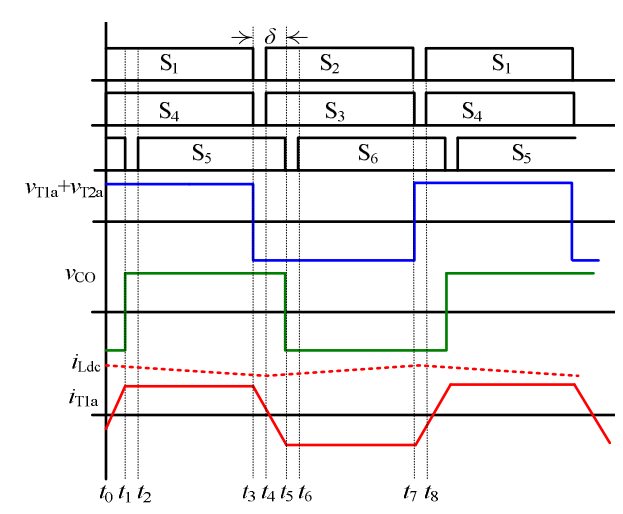

Figure 2: Key waveforms in Boost mode with two voltage levels.

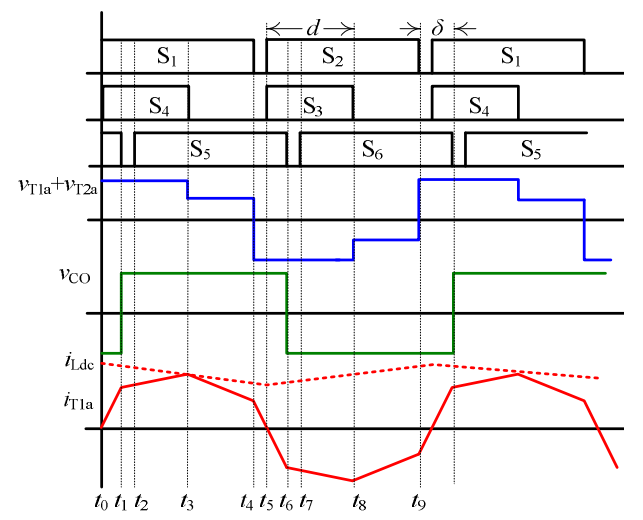

Figure 3: Key waveforms in Boost mode with three voltage levels.

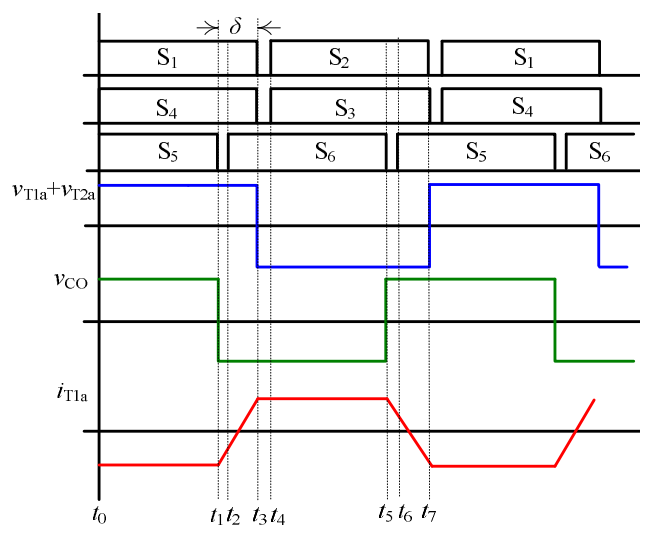

Figure 5: Key waveforms in Buck mode with two voltage levels.

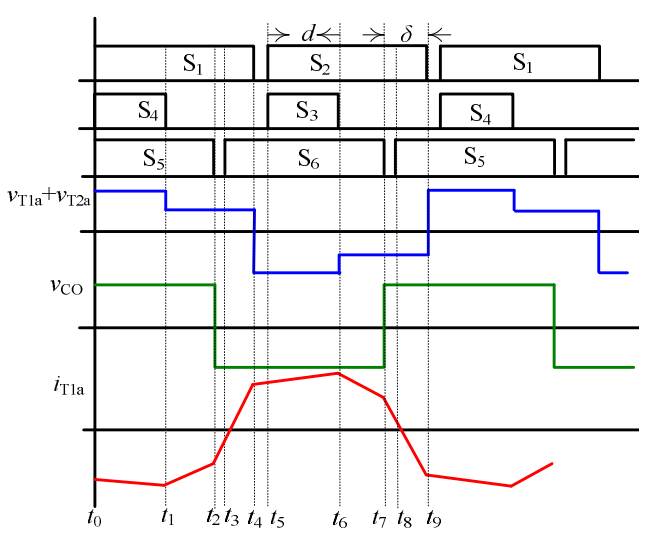

Figure 6: Key waveforms in Buck mode with three voltage levels. 


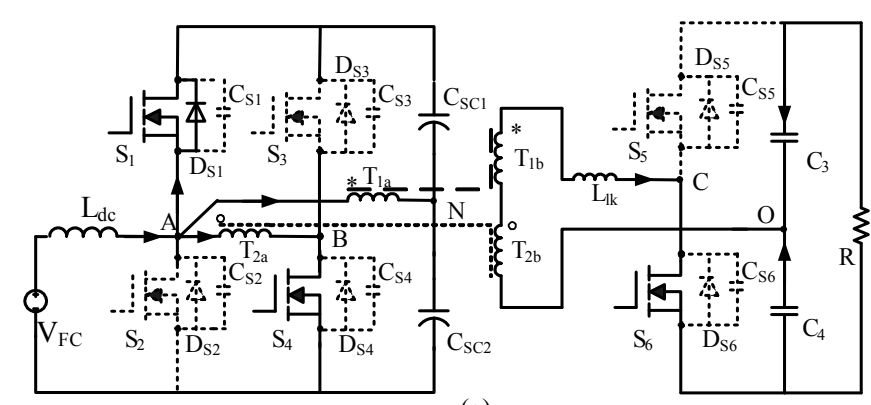

(a)

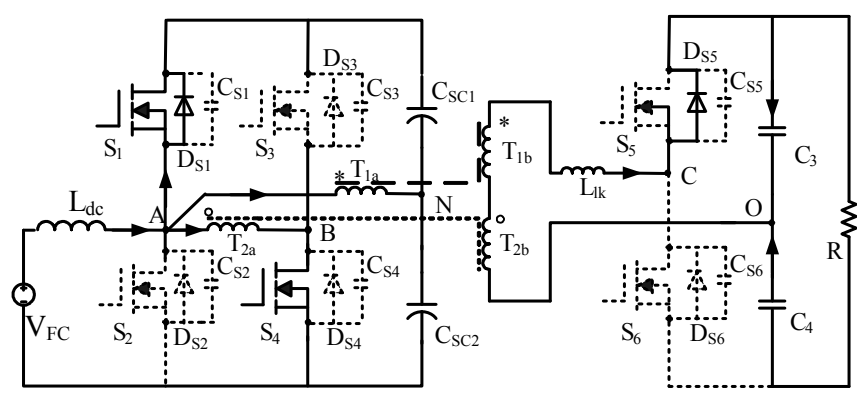

(c)

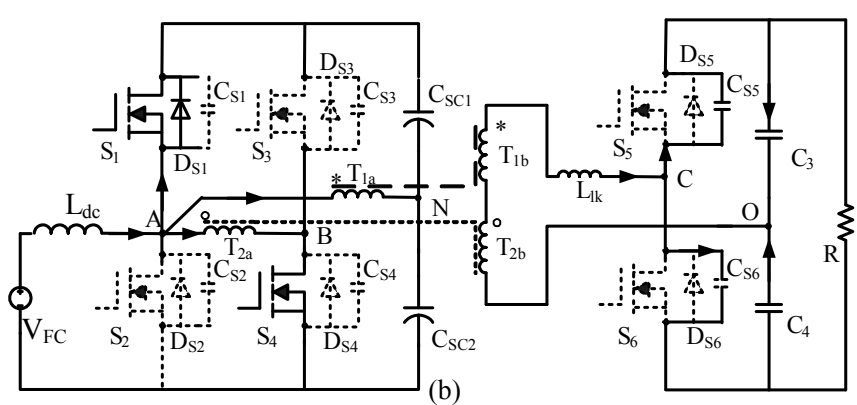

(b)

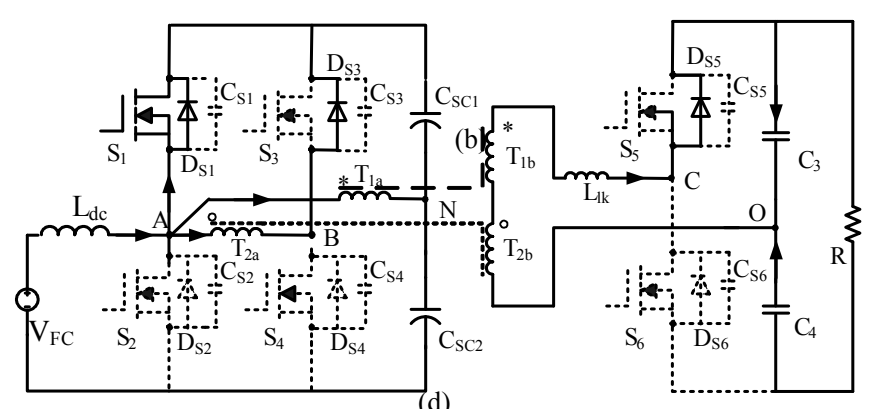

(d)

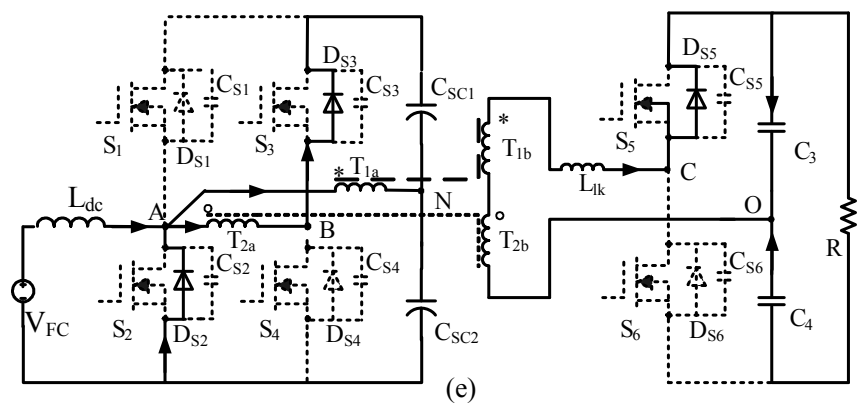

(e)

Fig 4: Equivalent circuits in Boost mode for half switching period (a) Interval $1\left(t_{0}-t_{1}\right)$ (b) Interval $2\left(t_{1}-t_{2}\right)$ (c) Interval $3\left(t_{2}-t_{3}\right)$ (d) Interval $4\left(t_{3}-t_{4}\right)$ (f) Interval $5\left(t_{4}-t_{5}\right)$

attempts to overshoot the negative rail. $D_{\mathrm{S} 2}$ is forward biased. During this period, $S_{2}$ can be turned on under ZVS.

After $t_{5}$, the second half cycle starts which is similar to the first half cycle.

\section{B. Buck mode}

The function of bidirectional power flow is necessary for charging the supercapacitors in Buck mode. Due to the reversed power-flow direction, the gate drive signal of $S_{5}$ is leading to that of $S_{1}$, as shown in Fig. 5. During the charging process, the voltage on the supercapacitors is increased, so the phase-shift plus duty cycle control is utilized in Buck mode. Because the half-bridge topology of the two sides is symmetrical, the operation principles in buck mode are similar to those in boost mode. But the fuel cells can not take the negative current, so there is no $I_{L d c}$ in Fig. 5 and Fig. 6 . The Buck mode operation can also be divided into ten stages, and the description of each step can be analogously inferred and will not be discussed here.

\section{Fuel cells warm-up stage}

During the warm-up stage of the fuel cells, there is no output power from fuel cell yet, so there is no $I_{\mathrm{dc}}$ waveform in Fig. 3. , but the operation principles are similar with that in Boost mode.
In this period, supercapacitors are discharged to deliver the energy stored to the load. The terminal voltage cross the SCs is reduced. To limit the peak current, extend the ZVS range and improve efficiency in this stage, the phase-shift with duty cycle control is used as analyzed above, so the converter is operated in three-level operation mode.

\section{CHARACTERISTICS OF THE NOVEL CONVERTER}

\section{A. Output power}

The phase shift angle $\delta(-0.5 \pi \leq \delta \leq 0.5 \pi)$, which is defined as shown in Fig. 2 and Fig. 3, is used to control the magnitude and direction of the transmitted power in two-level sub-modes. The output power is similar with what described in [10] and [13], shown as:

$$
P=\frac{2 \cdot V_{L} V_{H}}{\pi \omega L_{l k}} \cdot \delta(\pi-|\delta|)
$$

where $V_{L}$ is the peak voltage value of the transformer secondary side, $v_{T 1 b}+v_{T 2 b} ; V_{H}$ is the peak voltage value of $v_{C O} ; \omega$ is the switching angular frequency. 
From (1), the power that can be delivered by this converter with phase-shift control is double than that in [13].

In multi-level modes, the output power is:

$$
P= \begin{cases}\frac{V_{L} V_{H}\left(2 \pi \delta-4 \delta^{2}+2 \delta d+\pi d-d^{2}\right)}{2 \pi \omega L_{l k}} & (0 \leq|\delta| \leq d) \\ \frac{V_{L} V_{H}\left(2 \pi \delta-2 \delta^{2}-2|\delta| d+\pi d+d^{2}\right)}{2 \pi \omega L_{l k}} & (d \leq|\delta| \leq 0.5 \pi)\end{cases}
$$

When $d=\pi$ in (2), the three-level operation mode shifts into two-level mode, and (2) is same with (1) as well. When $\delta=0$, the power can be controlled by:

$$
P=\frac{V_{L} V_{H}}{2 \pi \omega L_{l k}} \cdot d(\pi-d)
$$

From (3), it is clear that the delivered power can be controlled by duty cycle without phase-shift and that extend to another operation mode. However, this mode is out of range for this paper and will not be described here.

\section{B. Circulating Current}

Calculation on the waveforms in Figs. 3, yields the rms value of $i_{T 1 a}$, or $I_{T 1 a}$ :

$$
I_{T 1 a}=\sqrt{\frac{(\pi-\delta) I_{2}^{2}+\left((\pi-d) I_{3}+(d-\delta) I_{1}\right) I_{2}+(\pi+\delta-d) I_{3}^{2}-\delta I_{1} I_{3}+d I_{1}^{2}}{3 \pi}}
$$

where

$$
\left\{\begin{array}{l}
I_{1}=i_{T 1 a}\left(t_{1}\right)=\frac{\pi V_{H}+(4 \delta-d-\pi) V_{L}}{2 \omega L_{l k}} \\
I_{2}=I_{\text {peak }}=i_{T 1 a}\left(t_{3}\right)=\frac{(\pi+2 \delta-2 d) V_{H}+(3 d-\pi) V_{L}}{2 \omega L_{l k}} \\
I_{3}=i_{T 1 a}\left(t_{4}\right)=\frac{(2 \delta-\pi) V_{H}+(\pi+d) V_{L}}{2 \omega L_{l k}}
\end{array}\right.
$$

And because of the difference between the turn ratio of $\mathrm{T}_{1}$ and that of $\mathrm{T}_{2}$, the rms value of $i_{T 2 a}$ is:

$$
I_{T 2 a}=\frac{I_{T 1 a}}{\sqrt{N_{T 1-T 2}}}
$$

where $N_{\text {T1-T2 }}$ equals to $n_{2} / n_{1}$.

\section{ZVS ranges}

From Fig. 2 and Fig. 5, the conditions of soft switching in boost mode and Buck mode depend on the magnitude of $I_{\mathrm{T} 1 \mathrm{a}}$, $I_{\mathrm{T} 1 \mathrm{a}}+I_{\mathrm{T} 1 \mathrm{~b}}$ and $I_{\mathrm{Ldc}}$ at $t_{1}, t_{3}, t_{5}$ and $t_{7}$, respectively. So we can get the similar equations with those described in [10].

$$
\text { (Boost mode) }\left\{\begin{array}{l}
I_{T 1 a}\left(t_{1}\right)>0 ; \\
I_{T 1 a}\left(t_{3}\right)+I_{T 2 a}\left(t_{3}\right)>I_{L d c}\left(t_{3}\right) ; \\
I_{T 1 a}\left(t_{5}\right)<0 ; \\
I_{T 1 a}\left(t_{7}\right)+I_{T 2 a}\left(t_{7}\right)>I_{L d c}\left(t_{7}\right) .
\end{array}\right.
$$

(Buck mode) $\left\{\begin{array}{l}I_{T 1 a}\left(t_{1}\right)<0 \\ I_{T 1 a}\left(t_{3}\right)+I_{T 2 a}\left(t_{3}\right)>0 \\ I_{T 1 a}\left(t_{5}\right)>0 \\ I_{T 1 a}\left(t_{7}\right)+I_{T 2 a}\left(t_{7}\right)<0 .\end{array}\right.$

From the section II, the soft switching conditions in multilevel mode are shown in (7) and (8).

$$
\begin{gathered}
\text { (Boost mode) }\left\{\begin{array}{l}
i_{T 1 a}\left(t_{0}\right)+i_{T 2 a}\left(t_{0}\right)+I_{L d c}<0 ; \\
i_{T 2 a}\left(t_{0}\right)<0, i_{T 1 a}\left(t_{2}\right)>0 ; \\
i_{T 1 a}\left(t_{4}\right)+i_{T 2 a}\left(t_{4}\right)-I_{L d c}>0 ; \\
i_{T 2 a}\left(t_{4}\right)>0, i_{T 1 a}\left(t_{7}\right)<0 .
\end{array}\right. \\
\text { (Buck mode) }\left\{\begin{array}{l}
i_{T 1 a}\left(t_{0}\right)<0, i_{T 2 a}\left(t_{0}\right)<0 \\
i_{T 1 a}\left(t_{3}\right)+i_{T 2 a}\left(t_{3}\right)<0 \\
i_{T 1 a}\left(t_{5}\right)>0, i_{T 2 a}\left(t_{5}\right)>0 \\
i_{T 1 a}\left(t_{8}\right)+i_{T 2 a}\left(t_{8}\right)>0
\end{array}\right.
\end{gathered}
$$

\section{Input current ripple}

The input current ripple is limited by the inductor, $L_{\mathrm{dc}}$. The ripple current $\Delta I_{L d c}$ of input current $I_{L d c}$ can be calculated as:

$$
\Delta I_{L d c}=\frac{V_{F C} \cdot \Delta t}{L_{d c}}=\frac{\pi V_{F C}}{\omega L_{d c}}
$$

where $\Delta t$ is the on-time of switch $S_{2}$ during each switching cycle and $L_{\mathrm{dc}}$ is the input inductance.

\section{EXPERIMENTAL VERIFICATIONS}

In order to verify the operation principle of the proposed converter analyzed above, a prototype was built in lab. For the transformer turn ratio and leakage inductance design, it is necessary to satisfy the following criteria: 1) at heaviest load condition, to keep the DC bus voltage constant, $\varphi$ is limited under the maximum phase shift angle; 2) Trade-off between the turns ratio and auxiliary inductance is to lower RMS current and extend ZVS operation range.

TABLE I. SPECIFICATIONS, PARAMETERS AND COMPONENTS

\begin{tabular}{c|c}
\hline \hline Input voltage & $30-60 \mathrm{VDC}$ \\
\hline Output voltage & $400 \mathrm{VDC}$ \\
\hline Output power & $1 \mathrm{~kW}$ \\
\hline Switches $\mathrm{S}_{1} \sim \mathrm{S}_{4}$ & IRFP4568PBF $(150 \mathrm{~V} / 154 \mathrm{~A})$ \\
\hline Switches $\mathrm{Q}_{1}, \mathrm{Q}_{2}$ & IRFP450LC $(500 \mathrm{~V} / 14 \mathrm{~A})$ \\
\hline Transformer core & Ferrite N87, EI 64 \\
\hline Transformer turns, T1 & $4: 16=n_{1}$ \\
$\mathrm{~T} 2$ & $4: 8=n_{2}$ \\
\hline Input inductor $L_{\mathrm{dc}}$ & $80 u \mathrm{H}$ \\
\hline Auxiliary inductor & $60 u \mathrm{H}$ \\
\hline Switching frequency & $40 \mathrm{kHz}$ \\
\hline Digital controller & $\mathrm{TMS} 320 \mathrm{~F} 2808$ \\
\hline \hline
\end{tabular}




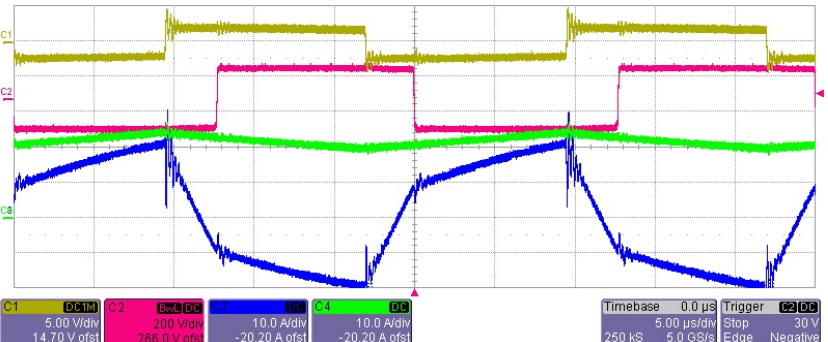

Figure7: Waveforms in Boost mode with two-level. CH1: $v_{\mathrm{T} 1 \mathrm{~b}}+v_{\mathrm{T} 2 \mathrm{~b}}(500 \mathrm{~V} / \mathrm{div})$ $\mathrm{CH} 2: v_{C O}(200 \mathrm{~V} / \mathrm{div}) ; \mathrm{CH} 3: i_{\mathrm{T} 1 \mathrm{a}}$ (blue $\left.10 \mathrm{~A} / \mathrm{div}\right) ; \mathrm{CH} 4: i_{L d c}($ green $10 \mathrm{~A} / \mathrm{div})$

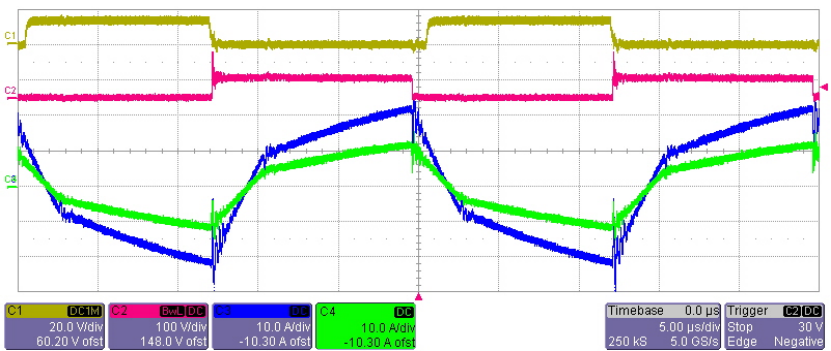

Figure 8: ZVS waveforms of the primary side switch in Boost mode with two voltage levels. CH1: $v_{G S S 2}(20 \mathrm{~V} / \mathrm{div}) ; \mathrm{CH} 2: v_{D S S 2}(100 \mathrm{~V} / \mathrm{div}) ; \mathrm{CH} 3: i_{\mathrm{T} 1 \mathrm{a}}$ (blue 10 $\mathrm{A} / \mathrm{div}) ; \mathrm{CH} 4: i_{\mathrm{Tlb}}($ green $10 \mathrm{~A} / \mathrm{div})$.

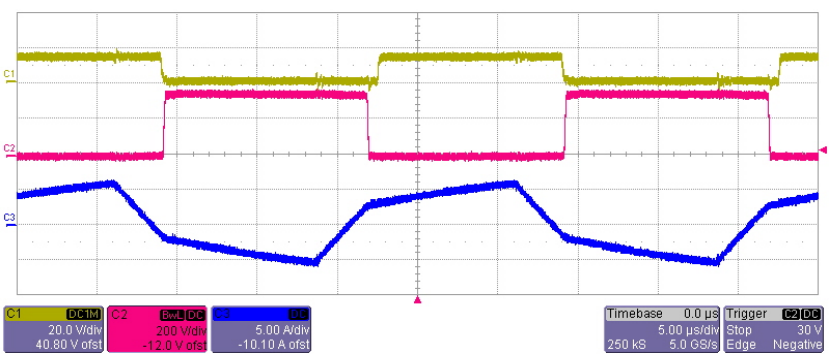

Figure 9: ZVS waveforms of the secondary side switch in Boost mode with two voltage levels.CH1: $v_{G S S 5}(20 \mathrm{~V} / \mathrm{div}) ; \mathrm{CH} 2: v_{D S S 5}(200 \mathrm{~V} / \mathrm{div}) ; \mathrm{CH} 3: i_{\mathrm{s}}(10 \mathrm{~A} / \mathrm{div})$.

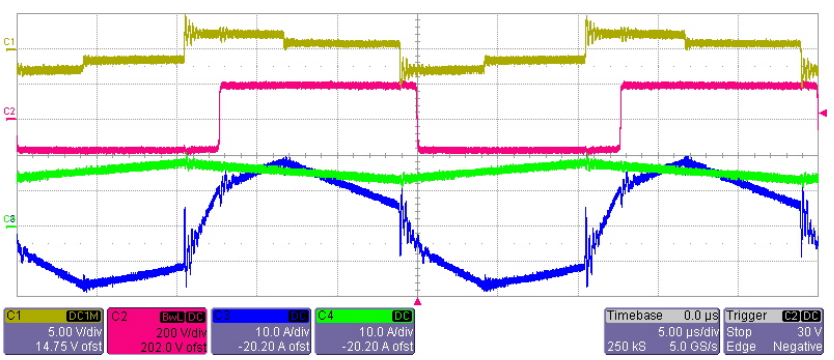

Figure 10: Waveforms in Boost mode with three voltage levels. $\mathrm{CH} 1: v_{\mathrm{T} 1 \mathrm{~b}}+v_{\mathrm{T} 2 \mathrm{~b}}$ $(500 \mathrm{~V} / \mathrm{div}) ; \mathrm{CH} 2: v_{C O}(200 \mathrm{~V} / \mathrm{div}) ; \mathrm{CH} 3: i_{\mathrm{T} 1 \mathrm{a}}$ (blue $\left.10 \mathrm{~A} / \mathrm{div}\right) ; \mathrm{CH} 4: i_{L d c}$ (green $10 \mathrm{~A} / \mathrm{div})$.

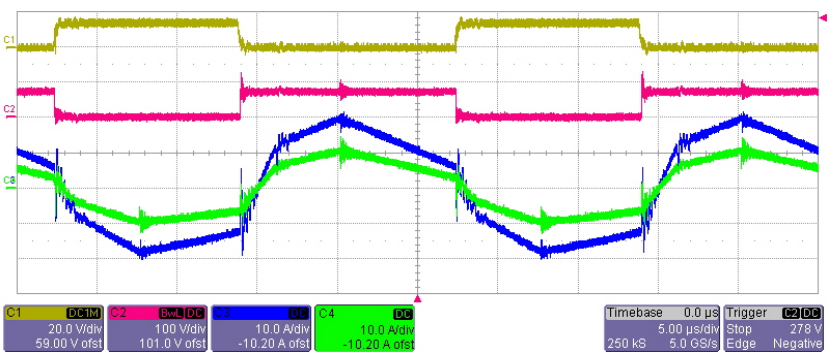

Figure 11: ZVS waveforms of the primary side switch in Boost mode with three voltage levels. CH1: $v_{G S S 2}(20 \mathrm{~V} / \mathrm{div}) ; \mathrm{CH} 2: v_{D S S 2}(100 \mathrm{~V} / \mathrm{div}) ; \mathrm{CH} 3: i_{\mathrm{Tl}}$ (blue $10 \mathrm{~A} / \mathrm{div}) ; \mathrm{CH} 4: i_{\mathrm{T} 1 \mathrm{~b}}$ (green $\left.10 \mathrm{~A} / \mathrm{div}\right)$.

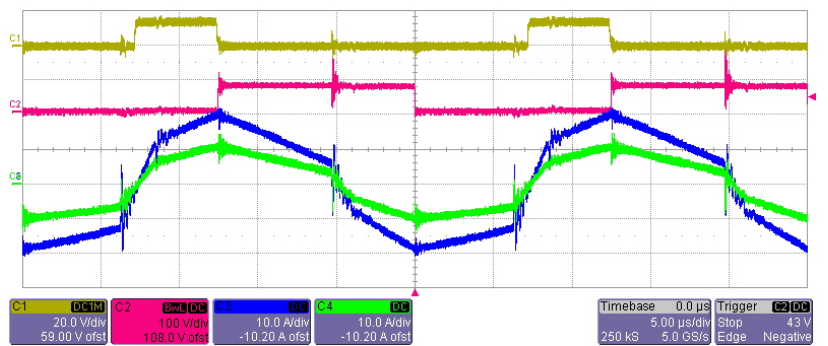

Figure 12: ZVS waveforms of the primary side switch in Boost mode with three voltage levels. CH1: $v_{G S S 4}(20 \mathrm{~V} / \mathrm{div}) ; \mathrm{CH} 2: v_{D S S 4}(100 \mathrm{~V} / \mathrm{div}) ; \mathrm{CH} 3: i_{\mathrm{Tla}}$ (blue $10 \mathrm{~A} / \mathrm{div}) ; \mathrm{CH} 4: i_{\mathrm{T} 1 \mathrm{~b}}$ (green $\left.10 \mathrm{~A} / \mathrm{div}\right)$

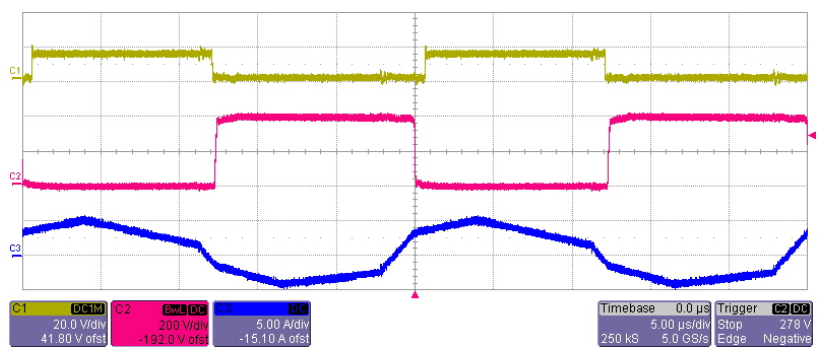

Figure 13: ZVS waveforms of the primary side switch in Boost mode with three voltage levels. CH1: $v_{G S S 4}(20 \mathrm{~V} / \mathrm{div}) ; \mathrm{CH} 2: v_{D S S}(200 \mathrm{~V} / \mathrm{div}) ; \mathrm{CH} 3: i_{\mathrm{s}}(10$ A/div).

To achieve high output power and low profile of the converter, two planar EI transformers were designed for the converter. In order to minimize the leakage inductance, a sandwiched winding structure was employed and the windings are arranged as: 2-turn (primary):8-turn (secondary):8-turn (secondary):2-turn (primary) for T1 and 2-turn (primary): 8turn (secondary):2-turn (primary) for T2. The transformers were tested by HP impedance analyzer, and the measured leakage inductances are $109 n \mathrm{H}$ and $103 n \mathrm{H}$ for $\mathrm{T} 1$ and $\mathrm{T} 2$, respectively, at $40 \mathrm{kHz}$. The leakage inductance is too small to be as the energy interface element in this converter, as shown in (1) and (2), so one extra inductor of $60 u \mathrm{H}$ was used at the secondary side of transformer for testing. The specifications of the converter are given in Table I.

The Figs. 7-13 show the experimental Boost mode waveforms at $550 \mathrm{~W}$, respectively. Fig. 7 and Fig. 10 show the waveforms of the primary voltage $v_{\mathrm{T} 1 \mathrm{~b}}+v_{\mathrm{T} 2 \mathrm{~b}}$, secondary voltage $v_{C O}$, primary side current $i_{T 1 \mathrm{a}}$ and input current $i_{L d c}$ under twolevel mode at $V_{F C}=30 \mathrm{~V}$, and three-level mode at $V_{\mathrm{FC}}=40 \mathrm{~V}$, respectively. The experimental waveforms are in agreement with Fig. 2 and Fig. 3.

Fig. 8 and Fig. 9 show the gate drive signal, voltage cross the drain and source of $S_{2}$ and $S_{5}$, the primary side current $i_{\text {T1a }}$ and $i_{\mathrm{T2}}$, and the secondary side current $i_{s}$, respectively, at $V_{F C}=30 \mathrm{~V}$, under two-level mode. Fig. 11, Fig. 12 and Fig. 13 show the ZVS conditions of $S_{2}, S_{4}$ and $S_{5}$, at $V_{F C}=40 \mathrm{~V}$ under three-level mode. All the switches shown in the figures realize ZVS on, and the experimental results are in agreement with the theoretical analysis well.

The efficiency in two-level mode at $V_{F C}=30 \mathrm{~V}$ and $V_{O}=400$ $\mathrm{V}$ is measured and efficiency curve illustrating the efficiency in different output power conditions is plotted in Fig. 14. At light load condition, the efficiency is lower, due to the primary side switches working under hard switching. Because the output 


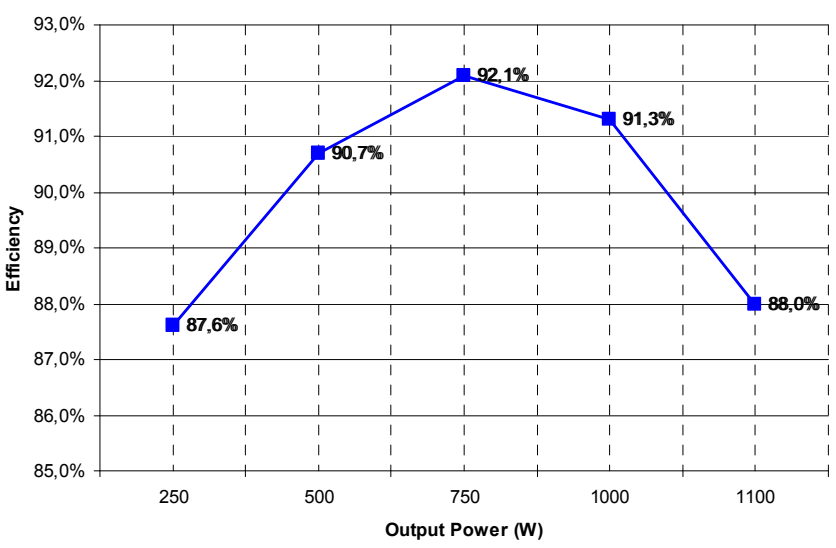

Figure 14: Efficiency curve

voltage of this converter is load-dependent, close-loop control must be used in the efficiency measuring. For the moment, we are designing and testing the close-loop control scheme under three-level mode, so the efficiency curve is not provided in this paper. But the efficiency measured at $V_{\mathrm{FC}}=40 \mathrm{~V}, V_{O}=400$ and $P_{O}=550 \mathrm{~W}$ under Boost three-level mode is $91.2 \%$.

\section{CONCLUSION}

A novel phase-shift and duty cycle controlled ZVS hybrid dc-dc converter with fuel cell and super capacitors is proposed, analyzed and designed in this paper. All the switches realize ZVS in wide range of load variation. Duty cycle control reduces the circulating current when the input voltage changed in wide range. It can be concluded, this bidirectional converter is suitable for the UPS system and HEV system.

\section{References}

[1] Josep M. Guerrero, "Uninterruptible power supply systems provide protection," in: IEEE Industrial Electronics Magazine, 2007, 1 (1) , p. 28-38.
[2] M. Becherif, M.Y. Ayad and A. Miraoui, "Modeling and passivity based control of hybrid sources: fuel cell and supercapacitors," Conference Record of the 2006 IEEE Industry Applications Conference Forty-First IAS Annual Meeting, vol.3, pp. 1134-1139, 2006.

[3] P. Thounthong, S. Rael, and B. Davat, "Control strategy of fuel cell and supercapacitors association for a distributed generation system," IEEE Transactions on Industrial Electronics, vol. 56, no. 6, pp. 3225-3233, 2007.

[4] D. Liu and H. Li, "A ZVS bi-directional DC-DC converter for multiple energy storage elements," IEEE Trans. Power Electron., vol. 21, no. 5, pp. 1513-1517, Sep. 2006.

[5] H. Tao, A. Kotsopoulos, J. L. Duarte and M. A. M. Hendrix, "Transformer-coupled multi-port ZVS bidirectional DC-DC converter with wide input range," IEEE Transactions on Power Electronics, vol. 23, no. 2, pp. 771-781, 2008.

[6] C. Zhao, S. D. Round, J. W. Kolar, "An isolated three-port bidirectional DC-DC converter with decoupled power flow management," IEEE Transactions on Power Electronics, vol. 23, no. 5, pp. 2443-2453, 2008.

[7] R. Wai, C. Lin and Y. Chang, "High step-up bidirectional isolated converter with two input power sorucees," IEEE Transactions on Inductrial Electronics, vol. 56, no. 7, pp.2679-2641, 2009.

[8] M. H. Todorovic, L. Palma and P. N. Enjeti, "Design of a wide input range DC-DC converter with a robust power control scheme suitable for fuel cell power conversion," IEEE Transactions on Industrial Electronics, vol. 55, no. 3, pp. 1247-1255, 2008.

[9] Z. Zhang, O. C. Thomsen, M. A. E. Andersen, "A Two-stage DC-DC Converter for the Fuel Cell Supercapacitor Hybrid System," IEEE Energy Conversion Congress and Exposition (ECCE 2009), Sept. 2009, San Jose, California, USA.

[10] F. Z. Peng, H. Li, G. J. Su, and J. S. Lawler, "A new ZVS bi-directional dc-dc converter for fuel cell and battery applications," IEEE Transactions on Power Electronics, vol. 19, no. 1, pp. 54-65, 2004.

[11] R. Ayyanar and N. Mohan, "Novel soft-switching dc-dc converter with full ZVS -range ans reduced filter requirement- Part I: Regulated output applications," IEEE Transactions on Power Electronics, vol. 16, pp. 184192, March, 2001.

[12] R. Ayyanar and N. Mohan, "Novel soft-switching dc-dc converter with full ZVS -range ans reduced filter requirement- Part II: Constant-input, variable output application," IEEE Transactions on Power Electronics, vol. 16, pp. 193-200, March, 2001

[13] J. Wnag, F. Z. Peng, J. Anderson, A. Joseph and R. Buffenbarger, "Low cost fuel cell converter system for residential power generation," IEEE Transactions on Power Electronics, vol. 19, no. 5, pp. 1315-1322, 2004. 